\title{
HOMENAGEM A JEAN LAPLANCHE
}

Christophe Dejours e Francis Martens

Christophe Dejours

Membro do

Conselho Científico

da "Fundação Jean

Laplanche, Novos

fundamentos para a

Psicanálise", Institut

de France.

Francis Martens

Membro do

Conselho Científico

da "Fundação Jean

Laplanche, Novos

fundamentos para a

Psicanálise”, Institut

de France.

Tradução

Pedro Henrique

Bernardes Rondon
- oi num piscar de olhos apoiado pelo destino que Jean La1 planche (21 de junho de 1924 a 6 de maio de 2012) faleceu este ano em Dijon, no dia do aniversário de nascimento de Freud (6 de maio de 1856). Com uma obstinação de camponês, esse neto de trabalhador em vinhedos não parou de labutar no campo freudiano, para reencontrar aí as linhas de força, as escapadas por pouco, a radical subversão, que a abundância de Freud, a babel em que resultou sua herança e o fato de ter sido resgatado pela moda, contribuíram para obscurecer tanto quanto para banalizar.

Formado em Beaune, antigo aluno da Escola Normal Superior, doutor em filosofia, com formação complementar em Harvard (onde encontrou o psicanalista Rudolph Löwenstein), esse mestre assistente na Sorbonne, depois professor em Paris VII, era também interno dos hospitais psiquiátricos da região do Sena. Ele devia esse outro curso a seu primeiro psicanalista — Jacques Lacan, em 1947 — o qual, em busca de lugares-tenentes, e tendo reconhecido a exigência intelectual desse analisando, intimou-o a estudar medicina. Isso não o impediu de se tornar, além disso, viticultor e produtor de vinhos (Château Pommard).

Em 1943, Jean Laplanche se descobre portador de mensagens para a resistência nos arredores de Beaune. Em 1948, com Cornelius Castoriadis e Claude Lefort, faz parte dos fundadores do grupo de pensadores antistalinistas "Socialismo ou Barbárie”. Participa também, em 1963, com Wladimir Granoff, Jean-Claude Lavie e Daniel Widlöcher, da fundação da Associação Psicanalítica da França (APF), onde muitos companheiros da primeira hora decidem marcar seu afastamento das práticas lacanianas.

Jean Laplanche, na esteira da célebre “Carta 52” (1896) de um Freud ainda próximo das neurociências de seu tempo, é 
o autor de uma teoria do recalcamento como parte do fracasso parcial da "tradução" imposta à criança pela parte sexual — intrusiva — que, à sua revelia, vem lastrar as mensagens remetidas pelos adultos por ocasião dos primeiros cuidados dispensados aos bebês. É também, entretanto, o iniciador e diretor científico da nova tradução e da edição crítica — sem equivalente - das obras completas de Freud, para a PUF (com a colaboração digna de nota de Janine Altounian, André Bourguignon, Pierre Cotet, Alain Rauzy, François Robert), publicação cujo último volume de escritos propriamente psicanalíticos sai em 2012 ("A frase de espírito”).

Laplanche é universalmente conhecido, no mundo das ciências humanas, por seu Vocabulário da psicanálise (PUF, 1967), elaborado em colaboração com Jean-Bertrand Pontalis. Os psicanalistas das mais diversas escolas sempre terminam, em caso de dúvida, referindo-se a essa obra singular que, com o máximo rigor, se dedica a articular de maneira lógica e histórica o conjunto dos conceitos freudianos. Minuciosa e crítica, desprovida de qualquer intenção hagiográfica, a obra de Laplanche (inaugurada por sua tese Hölderlin ou a questão do pai, de 1959) se interessa — num "retorno a Freud" marcado por sua "fidelidade infiel" (uma vez que Freud se esquece de ser freudiano) - por liberar racionalmente e com grande clareza o essencial da metapsicologia.

No cerne desta, cintila a noção de pulsão como campo de força rigorosamente diferenciado do de instinto, uma vez que provém da intensidade original, para a criança, da relação primordial com o outro. Na esteira freudo-laplancheana, de fato, o "sexual" em nada se confunde com o sexuado, o genital, o genésico, e ainda menos com o gênero. Tendo atravessado minuciosamente a herança pós-freudiana — Klein, Bion, Winnicott, Lacan, Schafer, Fonagy etc.- na qual, apesar de grandes avanços, o essencial da metapsicologia corre sempre o risco de se perder, a obra de Laplanche se alia à de Ferenczi (1873-1933) para a refundação da teoria generalizante da sedução. Essa refundação se cristaliza em 1987, em Novos fundamentos para a psicanálise (PUF, 1980-2006) à margem do ensino em Paris VII.

Imaginar que a noção de realidade psíquica ou de fantasia inconsciente — específica da teoria psicanalítica — seria 
procedente da negação, por Freud, da teoria da sedução, põe em relevo um conjunto de imagens e um mal-entendido desmentidos sem cessar pelos textos e pela prática de seu autor. Saído de um dispositivo clínico apto a permitir a expressão do inconsciente individual sexual recalcado, a metapsicologia não para de alimentar de volta a clínica para fazer dela uma práxis em que o "sexual", sob a forma menos biológica possível, se vê interrogado sem cessar. De um ponto de vista epistemológico, a teorização que surge daí tanto é estritamente racional em sua articulação quanto se revela falsificável no sentido popperiano do termo (apesar de alguns equívocos). Por não se prestar à pesquisa experimental, a metapsicologia nem por isso é menos um modelo científico fecundo e refutável.

Outra coisa são as derivas sectárias que viram a psicanálise se excluir do debate - e que, não sem razão, lhe valeram algumas boas cipoadas. Num outro planeta, hermética aos efeitos da moda, a obra de Laplanche remete a de Freud ao mais vivo de sua especificidade: a de uma leitura racional da abundância humana, desembocando numa antropologia solidamente presa à realidade, tanto quanto a múltiplas práticas clínicas em que se conjugam e se diferenciam, sem se excluir, os tempos psicoterápicos e psicanalíticos da síntese e da análise. À medida que o tempo passa, a refundação freudo-laplancheana da psicanálise esposa cada vez mais a linha clara de Hergé. São evidências disso seus dois últimos textos escritos: Entre séduction et inspiration, l'homme (PUF, 1999) e "Sexual", Le sexuel au sens freudien (PUF, 2007).

Estrangeiro a toda sedução, o autor da teoria da sedução generalizada nunca teve discípulos: terá tido, antes, colegas seduzidos — talvez mesmo consolados — por sua refundação do pensamento freudiano. Porque, nesta época em que pensar já é resistir, sob a pena de Laplanche, nada mais novo do que Freud! 